\begin{tabular}{|c|c|c|c|c|c|c|}
\hline \multirow{4}{*}{ Impact Factor: } & ISRA (India) & $=3.117$ & SIS (USA) & $=0.912$ & ICV (Poland) & $=6.630$ \\
\hline & ISI (Dubai, UAE & $=0.829$ & РИНЦ (Russia) & $=0.156$ & PIF (India) & $=1.940$ \\
\hline & GIF (Australia) & $=0.564$ & ESJI $(\mathrm{KZ})$ & $=8.716$ & IBI (India) & $=4.260$ \\
\hline & JIF & $=1.500$ & SJIF (Morocco) & $=5.667$ & OAJI (USA) & $=0.350$ \\
\hline
\end{tabular}

SOI: $1.1 /$ TAS
International Scientific Journal
Theoretical \& Applied Science
$\begin{array}{ll}\text { p-ISSN: } 2308-4944 \text { (print) } & \text { e-ISSN: } 2409-0085 \text { (online) } \\ \text { Year: } 2019 \quad \text { Issue: } 05 \quad \text { Volume: } 73 \\ \text { Published: } 30.05 .2019 \quad \text { http://T-Science.org }\end{array}$

SECTION 13. Geography. History. Oceanology. Meteorology.
QR - Issue

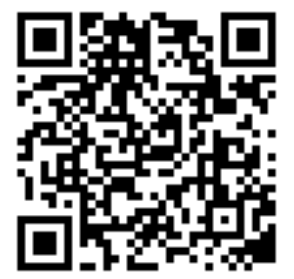

QR - Article

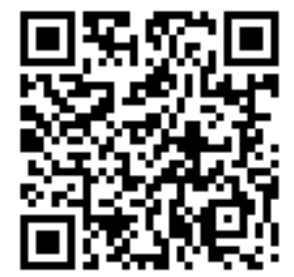

R.N. Tursunov

PhD., Docent

National University of Uzbekistan,

Tashkent, Republic of Uzbekistan ravshan.tursunov.1980@mail.ru

\title{
ECOLOGICAL CONDITION AND MYSTERIES IN TURKESTAN PERIODICAL PRESS IN THE EARLY XX CENTURY (IN THE CASE OF SADOI FERGHANA NEWSPAPER)
}

Abstract: This article explores the ecological condition in Turkistan, natural disasters and its consequences in the early XX century on the pages of the Sadoi Ferghana newspaper. In the Fergana valley, floods have been caused by natural disasters, such as heavy rains, floods, rainfall, snow and ice melting in the mountains. Also, as a result of natural disasters, the ecological situation in the country, the damage to the environment, namely the population, agricultural crops, has been scientifically studied.

Key words: Ecology, ecological condition, ecological problems, environment, periodical press, river, stream, natural disasters, precipitation, wind, flood, hail, weather, climate, climatology, air temperature.

Language: English

Citation: Tursunov, R.N. (2019). Ecological condition and mysteries in Turkestan periodical press in the early XX century (in the case of Sadoi Fergana newspaper). ISJ Theoretical \& Applied Science, 05 (73), 570-574.

Soi: http://s-o-i.org/1.1/TAS-05-73-89 Doi: rossef https://dx.doi.org/10.15863/TAS.2019.05.73.89

\section{Introduction}

As in the rest of the world, there are many natural disasters, such as floods, floods, earthquakes, fires, and harmful insects in the territory of Uzbekistan from ancient times to today. From this point of view, it is important to study the history of the ecological problems, their origins and consequences.

In the late XIX and early XX centuries the interests of the strongest powers in the world, the socio-economic situation in many countries, and the participation of the Russian Empire in the First World War also caused certain socio-economic and political problems for Turkestan. In such severe conditions, catastrophic natural disasters have posed serious threats to the livelihoods, socio-economic life of the population.

At the beginning of the XX century a number of natural disasters were observed in Turkistan, and these natural phenomena, as mentioned above, have shown its negative impact on society. The Sadoi Ferghana newspaper, which began its publication in the Ferghana Valley on April 3, 1914, is an important historical source for the study of the history of the ecological situation and problems of this period.

In the pages of the newspaper, in the beginning of the XX century, theoretical and practical work on the natural phenomena in Turkistan, its consequences and natural disasters, weather, agriculture, water and irrigation in the country, negative effects of harmful insects in the field of agriculture and horticulture environmental issues are regularly published in the form of news, announcements and articles.

\section{Materials and methods}

Note the weather reported on May 4, 1914, that at the end of April and beginning of May, temperatures were cold and fell to 6-7 degrees, even in Kokand, where crops were frozen, and dehkans planted cotton again. The newspaper writes that "In recent days, the weather is raining slightly below 6-7 degrees Celsius. They are afraid that it will affect the crops and the cotton fields. There were fresh red hot pits on the cotton fields in Khanty-Mansiysk. Eggand peasants were educated by firms and graduated from the autumn cotton trades. This year, the zakât was lighter and more than a bull. If the culture was more dangerous and less, they would have to do more about the safeguard" [1].

The "River Tank" published on the Sadoi Fergana page in the May 16, 1914, says that in Andijan there was a flooding of the Karadarya and Shahrikhan rivers. As a result, the houses and crops 


\begin{tabular}{llllll} 
& ISRA (India) $=\mathbf{3 . 1 1 7}$ & SIS (USA) $=\mathbf{0 . 9 1 2}$ & ICV (Poland) & $\mathbf{= 6 . 6 3 0}$ \\
Impact Factor: & ISI (Dubai, UAE) $=\mathbf{0 . 8 2 9}$ & PUHЦ (Russia) $=\mathbf{0 . 1 5 6}$ & PIF (India) & $=\mathbf{1 . 9 4 0}$ \\
& GIF (Australia) $=\mathbf{0 . 5 6 4}$ & ESJI (KZ) & $\mathbf{8 . 7 1 6}$ & IBI (India) & $=\mathbf{4 . 2 6 0}$ \\
& JIF & $\mathbf{1 . 5 0 0}$ & SJIF (Morocco) $=\mathbf{5 . 6 6 7}$ & OAJI (USA) & $\mathbf{0 . 3 5 0}$ \\
\hline
\end{tabular}

were seriously damaged by rivers and streams. In order to overcome this natural disaster, work and service workers were sent to the flood-ravaged areas and the river and its canals were repaired by "hashar".

"These days Karadarya has been hit hard around Andijan. That is why the shakhrikhon River also falls off the shores of the shore and the crops are flooded. The Black Sea Coasters have been sent out to serve the big watercourses of the coast, and they are doing good works in order to pour water into the waters of the Black Sea" [2].

A report by the Turkistan news on June 1, 1914 says that floods in Namangan on May 2, 1914 caused flooding of 1,1900 tanks in Hodjaabad and Uighur villages as a result of the flood, causing great damage to agricultural crops [3].

On May 30, 1914, in the pages of the newspaper, on May 20, 1914, a strong ice hole in Turkistan, the size of ice was chicken, as a result of which the windows were damaged as a result of the fall and damage to crops [4].

On May 30, 1914, Sadoi Ferghana published an article titled "Hail and ice" in the East Turgai volcano of the Vernyi region of Ettisuvi region on May 10, 2014 when the size of the hailstones was higher, then the size of the chicken eggs, and the ice did not melt for 4-5 hours. The report also notes that agricultural crops in Volga are not well-developed in this natural disaster. "The crops are worse than ever before, and they continue to grow. Now they are completely destroyed by ice" [5].

On June 18, 1914, the Sadoi Ferghana newspaper published a report on May 19, 1914, in It Olgiqisyo village of Isfara province of Khujand city of Samarkand region as a strong, chick-borne widow and frostbite, as a result of the rapid melting of ice, as a result some villagers the fact that this natural disaster has also hit human lives.

The thickness of the ice drops to half-gas. This is a huge flood of ice, and the two canals are located on the canary. In one of these homes, there is a 70-yearold sick Muslim. This is a flowing nest with the country, without leaving the poor home. Then he found his corpse in 100 pieces of cinnamon. In this village, 1360 soum damage has been inflicted across the country. But there is also a great deal of damage to other neighboring countries and cultivated lands" [6].

On June 18, 1914, in the 31st issue of the newspaper, the Andijan massacre of the Ferghana region occurred on the 28th of May, 1914 in Kokand, causing great damage to the environment. The news says that this rainfall in the Kokand has damaged 17,000 sums [7].

The report titled "The Flood Results", published in the newspaper, June 22, 1914, stresses that nearly half a million sums have been lost in recent floods around the Shahrikhon River [8]. As a result of this flood, 300 desyatina from the Kurgantepa, Ayim and Karasu were destroyed by rice and cotton crops and the crops were re-planted by farmers. It is also noted that in the middle of June, the Naryn River was flooded and damaged by the environment and vegetation.

The "Damage to crops" article 36 of Sadoi Fergana, published in June 29, 1914, outlines the total amount of damage caused by natural disasters in the areas of Skobelev and Namangan in Fergana Region in June, as a result of heavy rainfall, damage to residential areas. "Skobelov around the Ararat valley, with heavy rains in Khogand, Kishlong village, 10 hectare in the Kulin village, 45 hectare cotton was damaged. In the Chust volost of Namangan 405 hectare of cotton, 69 hectare wheat, 16 hectare of barley, 14 hectare vineyards, 27 hectare of other orchard gardens were damaged. All of these villages have been planted in the area by 134 trees.All the damage was 2537 soums.

In the Vorzin village there are 49 hectare of wheat, 18 hectare maize, 56 hectare of cotton and 3 hectare of barley. Damage is 1595 soums. The glacial volost Kuvanarig is located in the desert with 248 hectare of Amrikon cotton, 22 hectare of wheat and 2 grapes and other fruits. Damage. 2736 sums [9].

In the early part of the 20th century, the focus was on floods, rainfall and flooding in Turkistan, mainly in the late spring and early summer months. The reason for this is that in these months climates in the country are warm, the temperature is very warm, the melting of ice in the mountains and snow melts to its highest point.

American diplomat E.Schuyler's "Turkiston: Travel to Russia, Turkestan, Kokand, Bukhara and Guljaga records" also provides valuable information about climate, weather and nature in Turkestan. The fact that E.Schuyler's views on the nature and climate of Turkistan is comparable with the data presented in local sources, the fact that the information is almost always coincidental confirms that the author's observations in the country are accurate and objective.

E.Schuyler describes the river in winter as follows: "During the winter, when the river is slippery, and the surface of the stream is gradually unstable, it is covered with fine ice, which raises one person. The river's water rises three times: from early rains to early spring and autumn, from summer to summer, from ten feet to fifteen feet" [10, P. 244].

It is well known that in the late 19th and early 20th centuries, textile factories in the Russian Empire were mainly cultivated in Turkistan. Cotton raw material produced in Turkistan was delivered by local merchants and foreign firms to the imperial area.

This cooling of the air has seriously amazed farmers and gardeners who are engaged in agriculture. The reason for this is that the cotton fields planted by 


\begin{tabular}{llllll} 
& ISRA (India) $=\mathbf{3 . 1 1 7}$ & SIS (USA) $=\mathbf{0 . 9 1 2}$ & ICV (Poland) & $\mathbf{= 6 . 6 3 0}$ \\
Impact Factor: & ISI (Dubai, UAE) $=\mathbf{0 . 8 2 9}$ & PUHЦ (Russia) $=\mathbf{0 . 1 5 6}$ & PIF (India) & $=\mathbf{1 . 9 4 0}$ \\
& GIF (Australia) $=\mathbf{0 . 5 6 4}$ & ESJI (KZ) & $\mathbf{8 . 7 1 6}$ & IBI (India) & $=\mathbf{4 . 2 6 0}$ \\
& JIF & $\mathbf{1 . 5 0 0}$ & SJIF (Morocco) $=\mathbf{5 . 6 6 7}$ & OAJI (USA) & $\mathbf{0 . 3 5 0}$ \\
\hline
\end{tabular}

farmers were purchased by foreign companies in advance. This has led farmers to work more responsibly. If the harvest was not good, farmers had to deal with many difficulties when they were unable to deliver a certain amount of cotton, according to a trade agreement with firms. That's why climatic and weather related information was extremely important for the dehans.

In his book "Turkistan", a professor of German studies at the University of Dorpat (Germany), Alexander Pettshold, contains valuable information about the climate, climate and nature of Turkestan. In particular, the author dwells on the climate of the country, "The Turkestan climate is continental because it is located in the center of the big region. It is hot and winter is cold. In general, there is droughts everywhere, rainfall is rare. In the summer and summer, the temperature in the desert and steppes will rise sharply and will reach 38-40 degrees in the shade. In the short run, the opposite is true: the desert and the coldest temperatures in the steppe. There are also moderate places in the summer and winter" [11, P. 8], which gives a fair assessment of the weather in Turkistan.

On May 11, 1914, in the Fergana valley, Ferghana news agency reported that during the month of April there were heavy rains and thunderstorms, and that the weather was not hot at the beginning of May, but that the weather was very hot, the second day is cool. On May 8, 1914, the weather was warm and the weather was not hot on May 9, and on May 10 it was raining heavy rains, and roads were hardly pedestrians. This news item also changes weather also has a negative impact on agricultural crops and has been planted again.

The news says that many of April's infected people have suffered from colds and heavy rains. Therefore, the sown earlier crops had not been exhausted and had to be planted on the other. Until the end of May, there is no air pollution. If one day is too hot, the second day will be cool. On $8^{\text {th }}$ may smaller africa was hot. The 9th may not be the case. It was difficult to walk on with heavy rains" [12].

On May 23, 1914, the "Kokands' News" newspaper published under the headline "About weather " published a report in Ferghana region on May 15-16, 1914 that the temperature reached 48 degrees and on May 20 it rained at 25-30 degrees Celsius [13].

According to the Sadoi Ferghana newspaper June 18, 1914, the weather in Ferghana was 40-45 ${ }^{\circ}$ C, [14] and on June 29, 1914, the temperature increased to 53-55 degrees [15], and on July 6, 1914, the temperature was $45^{\circ} \mathrm{C}-50$ degrees [16].

In the beginning of the 20th century, as in all Turkestan, in the Fergana region, it was also very hot in the end of May, June, and July.
Taking into account the warmth of summer in Turkistan, wealthy men, traders and factories tried to go to Russia and other cold countries to keep the heat in summer. This idea can be seen in the following newsletters: "Our wealthy men, merchants, manufacturers, and factories are filling our train every day to Daghestan, Russia and other cold countries. These days, people fleeing from the city of Kokand said that it is necessary to keep tickets for three or four days to get a ticket. The weather is 53-54 degrees in these days" [17].

In the summer months in Turkistan, there are many cool, mountainous, and mountain resorts. These include the Chimgan holiday zone today. It is clear from the sources that this beautiful, climatic climate was popular as a recreational place in the early 20 th century. In particular, in 1914, in the 26th issue of the Sadoi Fergana, it reads: "In the cold weather of Chimgan, the Chimgan invaders attract the population day by day. Even though it is the best place to get away from the heat for the Turkestan people, people are suffering only because of the difficult and expensive roads. It's 20 to 25 sums from Toshkend to Chimgan. But if you are in shock, it costs 50 rubles" [18].

Note that Yu. Skayler's view of the city of Tashkent is that in the summer, the population goes out of the city in order to escape the heat of heat [19, P. 52].

Of course, in the summer, there was a problem with the high quality of summer weather in Turkistan where the climate was warm and that the country brought good quality melons and gourds to other countries, bringing similar products to the country in good condition. It is also natural that traders and firms often deal with these issues in many cases.

At the beginning of the 20th century, the Russian Ministry of Transport developed a cold wagons project for the production of fruits and other frozen products. The important point is that on June 29, 1914, the Sadoi Ferghana newspaper reported that such wagons would start soon between Samarkand and Moscow and St. Petersburg. In particular, in the newspaper "The Russian Ministry of Roads are cold everywhere the wagons were accepted. Most of these things started to happen. In Turkestan, these wagons now begin to sink between Samarkand and Moscow in these days. Recently, other cities in Turkestan also see the passage of railroads in line with the railroad. These wagons are fast-moving and frustrated" [20].

According to the newspaper July 21, 1914, a slight rainfall at Kokand on July 17, 1914, according to the 48th edition of the newspaper, 1914, on August 1,1914 , rainfall over 2-3 times a day in Kokand, 3035 degrees, and around 10-12 degrees at night [22]. Thus, as is evidenced by the data, it is possible to 


\begin{tabular}{llllll} 
& ISRA (India) $=\mathbf{3 . 1 1 7}$ & SIS (USA) $=\mathbf{0 . 9 1 2}$ & ICV (Poland) & $\mathbf{= 6 . 6 3 0}$ \\
Impact Factor: & ISI (Dubai, UAE) $=\mathbf{0 . 8 2 9}$ & PUHЦ (Russia) $=\mathbf{0 . 1 5 6}$ & PIF (India) & $=\mathbf{1 . 9 4 0}$ \\
& GIF (Australia) $=\mathbf{0 . 5 6 4}$ & ESJI (KZ) & $\mathbf{8 . 7 1 6}$ & IBI (India) & $=\mathbf{4 . 2 6 0}$ \\
& JIF & $\mathbf{1 . 5 0 0}$ & SJIF (Morocco) $=\mathbf{5 . 6 6 7}$ & OAJI (USA) & $\mathbf{0 . 3 5 0}$ \\
\hline
\end{tabular}

observe gradual decrease of air temperature in Ferghana region starting from August.

At the beginning of the 20th century, when it comes to weather conditions in autumn and winter in Ferghana region, it is possible to see precipitation, ie rains and snow. On October 28, 1914, the Sadoi Fergana newspaper reported that the weather was rainy on October 23, 1914, and on October 24 it was raining by snow and snowfall in the evening on October 24, but the temperature was not cold [23].

According to data from December 30, 1914, in Kokand this year was fairly cold, when snowfalls broke through the first harvest of cotton harvesters in autumn, and the temperature was about 10-20 degrees from early December. The report also said that coal, coal and coal prices have increased. Because of the cold weather in the last year, the water was no longer ice, and in the summer there was a wagon bulb from the city. Xolo keeps all the ponds and pools clean. This year the ice store should be filled" [24], thus emphasizing that water supply and water resources in the Ferghana Valley in 1915 would be enough.

In the 107th issue of 1915, in the Fergana region, the January weather was reported: "In the Fergana tunnel, the weather was good since January 10, when the streets of Kokand and Margilan were dry, some farmers worked, they were throwing stones and even raining down the wounded Margilan raven. Even though the streets are in the city of Andijan, the pavement is open in the midst of the market and the pedestrian path is in the midst of the neighborhood. On January 23-24, Andijan, Margilan, the snowstorm and the heavy rains were mud. On January 26, the wind in Khujand was cold and the weather was cold" [25]. This message also provides information on the state of roads in the city infrastructure, that is, the roads that have been crushed and paved (land roads). Of course, traffic on the paved roads (horses and pedestrians) has also been a source of comfort for all seasons. Roads were dry during the summer, but traffic on rocky roads was not difficult, but the dust extinction had a negative impact on the environment, human health, and ecology. It is natural that during the rainfall, on land routes, passengers and horses have a serious discomfort.

\section{Conclusion}

In summary, it can be said that the Sadoi Ferghana newspaper regularly reports on climatic and weather conditions in the country, firstly, indicates the development of climatology in the country, and secondly, agriculture and other sectors of the national economy are involved in agriculture, livestock and horticulture and planning to do the job according to the weather data. However, it should be noted that the weather data published on the pages of the newspaper "Sadoi Ferghana" Weather forecast is very rare, and the weather forecast is rare.

The essence and meaning of the foregoing news is that, firstly, the authors have consistently studied the nature, environment and ecology information, news and articles published in the newspaper, and, secondly, the authors have described the processes of nature and society, nature phenomena, it is understood that they are aware of nature-related natural knowledge.

In general, information from the Sadoi Ferghana newspaper, which is a reputed press in the study of the history of climate, ecological situation and problems in the Turkestan era in the early 20th century, is an important source.

\section{References:}

1. (1914, May 4). Kokand news. Sadoi Ferghana.

2. (1914, May 16). River floods. Turkistan News. Sadoi Ferghana.

3. (1914, June 1). Turkistan News. Sadoi Fergana.

4. (1914, May 30). Hail in Turkestan. Turkistan News. Sadoi Ferghana.

5. (1914, May 30). Frozen again. Turkistan News. Sadoi Ferghana.

6. (1914, June 18). Big hurricane and ice. Turkistan News. Sadoi Ferghana.

7. (1914, June 18). Big Flood. Turkistan News. Sadoi Ferghana.
8. (1914, June 22). Flood effect. Turkistan News. Sadoi Ferghana.

9. (1914, June 29). Damage to crops. Sadoi Ferghana.

10. Schuyler, E. (2019). Turkestan: Travel to Russia, Turkestan, Kokand, Bukhara and Gulja. Translator Z. A. Saidboboyev. (p.214). Tashkent: Uzbekistan.

11. Petzholdt, A. (1874). Turkestan. Auf Grundlage einer im Jahre 1871 unternommenen Bereisung des Landes. (p.8). Leipzig.

12. (1914, May 11). Weather of Kokand. Sadoi Ferghana. 


\begin{tabular}{llllll} 
& ISRA (India) $=\mathbf{3 . 1 1 7}$ & SIS (USA) $=\mathbf{0 . 9 1 2}$ & ICV (Poland) & $\mathbf{= 6 . 6 3 0}$ \\
Impact Factor: & ISI (Dubai, UAE) $=\mathbf{0 . 8 2 9}$ & PUHЦ (Russia) $=\mathbf{0 . 1 5 6}$ & PIF (India) & $=\mathbf{1 . 9 4 0}$ \\
& GIF (Australia) $=\mathbf{0 . 5 6 4}$ & ESJI (KZ) & $\mathbf{8 . 7 1 6}$ & IBI (India) & $=\mathbf{4 . 2 6 0}$ \\
& JIF & $\mathbf{1 . 5 0 0}$ & SJIF (Morocco) $=\mathbf{5 . 6 6 7}$ & OAJI (USA) & $\mathbf{0 . 3 5 0}$ \\
\hline
\end{tabular}

13. (1914, May 23). About weather. Sadoi Ferghana.

14. (1914, June 18). About weather. Reporter's of Kokand. Sadoi Ferghana.

15. (1914, June 29). About weather. Reporter's of Kokand. Sadoi Ferghana.

16. (1914, July 6). About weather. Reporter's of Kokand. Sadoi Ferghana.

17. (1914, June 4). Kokand news. Sadoi Ferghana.

18. (1914). Turkistan news. Sadoi Fergana. 26th.

19. Yu, Skayler (2019). Turkestan: Travel to Russia, Turkestan, Kokand, Bukhara and Gulja. Translator Z.A. Saidboboyev. (p.52). Tashkent: Uzbekistan.
20. (1914, June 29). Cold wagons. Various News. Sadoi Fergana.

21. (1914, July 21). Rain. Reporter's of Kokand. Sadoi Ferghana.

22. (1914, August 5). Air. Reporter's of Kokand. Sadoi Ferghana.

23. (1914, October 28). Airborne. Reporter's of Kokand. Sadoi Ferghana.

24. (1914, December 30). Kokand News. Sadoi Ferghana.

25. (1915). Ferghana's Air. Sadoi Fergana, issue 107. 